\title{
Sedimentary environment controls on the accumulation of organic matter in the Upper Ordovician Wufeng-Lower Silurian Longmaxi mudstones in the Southeastern Sichuan Basin of China
}

\author{
Lei Yang ${ }^{1} \cdot$ Bo Ran ${ }^{2} \cdot$ Yu-Yue Han ${ }^{2} \cdot$ Shu-Gen $\mathrm{Liu}^{2} \cdot$ Yue-Hao $\mathrm{Ye}^{2} \cdot$ Christopher Xiao $^{3} \cdot$ Wei Sun $^{2} \cdot$ \\ Di Yang ${ }^{2} \cdot$ Guo-Dong Xia ${ }^{2} \cdot$ Shi-Yu Wang ${ }^{4}$
}

Received: 31 May 2018/Published online: 13 December 2018

(C) The Author(s) 2018

\begin{abstract}
The Upper Ordovician-Lower Silurian mudstones (including the Wufeng, Guanyinqiao and Longmaxi Formations) in the Sichuan Basin are some of the most important shale gas plays in China. In order to enhance our understanding of the process of formation of organic carbon up to $10 \%$, optical, microscopy and geochemical methods have been used to investigate the petrographic and geochemical characteristics of the formation. Firstly, three mudstone lithofacies were identified based on a wide variety of mudstone laminations. These are: (a) indistinctly laminated mudstone; (b) parallellaminated mudstone; and (c) nonparallel-laminated mudstone. Then, combining with the evidence from depocenter migration, $\mathrm{Th} / \mathrm{U}$ ratios and total organic carbon, the abundant organo-minerallic fabrics suggest that organic carbon was preferentially deposited and preserved in anoxic, low energy and stagnant water conditions during deposition of the Wufeng and Longmaxi Formations. On the contrary, the Guanyinqiao Formation with poor organic carbon was deposited in oxic and high-energy water conditions.
\end{abstract}

Keywords Guanyinqiao Formation $\cdot$ Sichuan Basin $\cdot$ Mudstone $\cdot$ Laminated mudstone $\cdot$ Water condition

\section{Introduction}

Very fine-grained mudstones typically consist of various materials, including clays, quartz, and organic matter (Macquaker and Bohacs 2007). In petroleum source rocks and shale gas reservoirs, organic matter is one of the most important components of black mudstones, so organic matter accumulation is a research focus (e.g., Potter et al.

Edited by Jie Hao

Bo Ran

ranbo08@cdut.cn

1 School of Earth Sciences and Resources, China University of Geosciences, Beijing 100083, China

2 State Key Laboratory of Oil and Gas Reservoir Geology and Exploitation, Chengdu University of Technology, Chengdu 610059, Sichuan, China

3 University of Houston, 4800 Calhoun Rd, Houston, TX 77004, USA

4 Research Institute of Yanchang Petroleum (Group) Co. Ltd, Xi'an 710075, Shaanxi, China
2005; Aplin and Macquaker 2011). The Upper OrdovicianLower Silurian marine mudstones in the southeastern Sichuan Basin are one of the most important source rocks and potential shale gas plays in China (e.g., Chen et al. 2011; Liu et al. 2013; Guo and Zhang 2014; Liang et al. 2016), but the variable mechanisms of organic matter accumulation restricts understanding about Chinese marine source rocks and shale gas development. In former studies, there were four different points for the mechanism of organic matter accumulation: (1) upwelling and suspension (Liang et al. 2016); (2) low preservation, high dilution, and high organic production ( $\mathrm{Li}$ et al. 2015); (3) a limited oxygen and anoxic environment (Liu et al. 2013; Yang et al. 2016); (4) high paleoproductivity and dysoxic/anoxic conditions (Zhao et al. 2016). These former studies were only based on geochemical and lithofacies data without constraints from mudstone lamination and the regional depositional environment. As a result, we have undertaken an investigation of the organic matter, lithofacies, mineralogy, and trace element composition of the mudstone using data from outcrops at different locations in the southeastern Sichuan Basin in this study. 


\section{Geological background}

The Sichuan Basin is a large tectonically stable and oil and gas-bearing superimposed basin in southwest China (Zhai 1989; Liu et al. 2012). During the Upper OrdovicianLower Silurian, the Sichuan Basin was covered by a broad epeiric sea and was bordered by the Qianzhong uplift to the south and the Chuanzhong uplift to the west (Fig. 1; Wang et al. 1997; Liang et al. 2008; Chen et al. 2014; Ran et al. 2016).

The Wufeng-Longmaxi mudstones of southeast Sichuan Basin are underlain by the Upper Ordovician Linxiang Formation and overlain by the Lower Silurian Shiniulan Formation. Across much of the southeast Sichuan Basin, the Wufeng-Longmaxi mudstones are subdivided into three different Formations: (1) the lower part, the Wufeng Formation is composed of black mudstone rich in graptolites and radiolaria; (2) the middle part, the Guanyinqiao Formation, is composed of gray or dark gray carbonate rocks rich in rugose corals, gastropods, bryozoa and bivalves; (3) the upper part, the Longmaxi Formation, is composed of black mudstone and dark gray siltstone rich in graptolites (Chen et al. 2004; Rong et al. 2011; Yan et al. 2009).
Fig. 2 Field photographs of the Wufeng, Guanyinqiao and Longmaxi Formations in the southeastern Sichuan Basin. a The Wufeng Formation in the Qilongcun section; b the Guanyinqiao Formation in the Xiushan section; $\mathbf{c}$ the Guanyinqiao Formation in the Daijiagou section; d the lower part of the Longmaxi Formation in the Xiushan section; e the lower part of the Longmaxi Formation in the Qilongcun section; $\mathbf{f}$ the Longmaxi Formation in the Guanyinqiao section; $\mathbf{g}$ the upper part of the Longmaxi Formation in the Qilongcun section; $\mathbf{h}$ the upper part of the Longmaxi Formation in the Xiushan section. The diameter of coin is $19 \mathrm{~cm}$

\section{Sampling and analytical methods}

\subsection{Sampling and experimental protocol}

Based on detailed observations from the fresh outcrops of this study, the Guanyinqiao (sample number-QJ), Daijiagou (sample number-DJG), Rongxi (sample numberCXS), and Qilongcun (sample number-TZ) sections contain a range of small-scale sedimentary features and stratification styles that suggest a variety of processes were involved in their deposition. Numerous microsedimentary textures and structures are present throughout the outcrops (Fig. 2).

The samples are necessary to describe the mudstone and silt mudstone in terms of sedimentary, petrographic and geochemical characteristics. A relatively complete experimental program was conducted and is listed in Table 1.
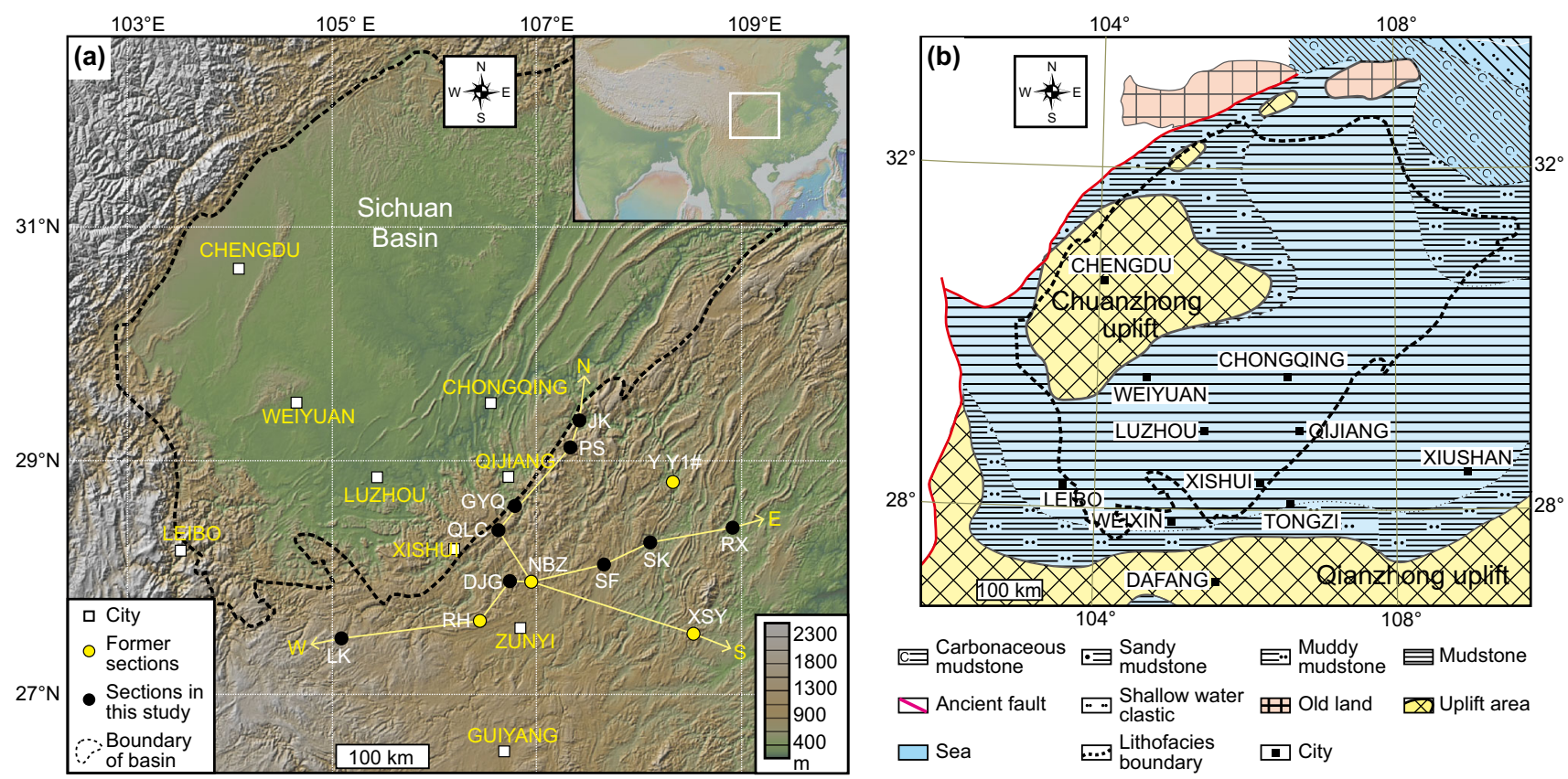

Fig. 1 a Topography of the Sichuan Basin and nearby regions derived from GeoMapApp digital elevation model. b Lithofacies paleogeographic map of the Sichuan Basin during the Early Silurian Longmaxi stage. (Modified from Chen et al. 2004) 

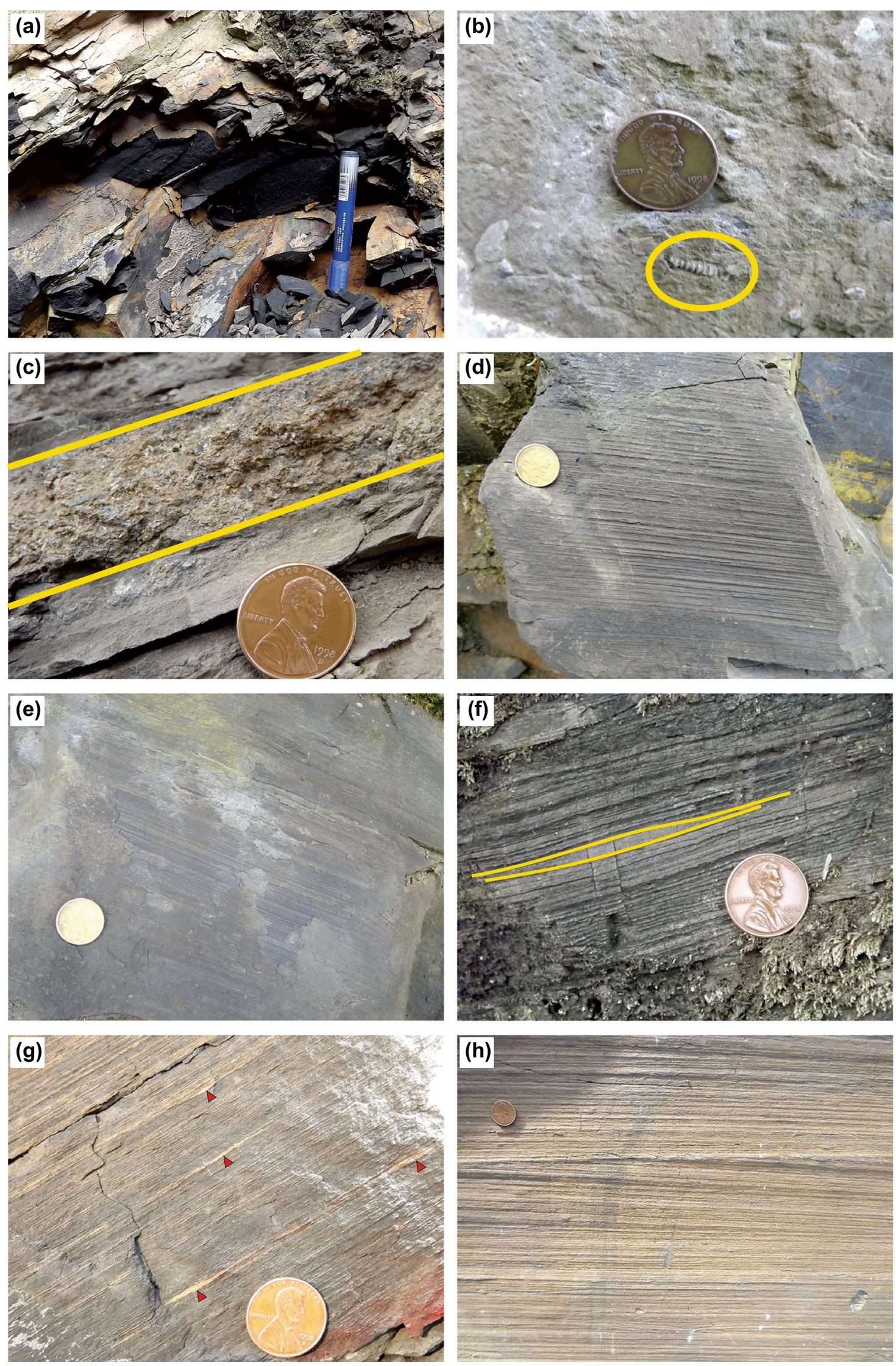
Table 1 Experimental programs

\begin{tabular}{ll}
\hline Test projects & Laboratory \\
\hline $\begin{array}{l}\text { Mineralogy: X-ray } \\
\text { diffraction }\end{array}$ & $\begin{array}{c}\text { State Key Laboratory of Oil and Gas } \\
\text { Reservoir Geology and Exploitation, CDUT } \\
\text { TOC }\end{array}$ \\
& $\begin{array}{c}\text { Experimental Center of Exploration and } \\
\text { Development Research Institute, }\end{array}$ \\
& PetroChina Southwest Oil and Gas Field \\
& Company, Chengdu \\
Trace elements & The Institute of Tibetan Plateau Research, \\
Microscopy & CAS, Beijing \\
& Key Laboratory of Tectonic Controlled \\
& Mineralization and Oil Reservoir, Ministry \\
& of Land and Resources, CDUT
\end{tabular}

\subsection{Analytical procedures}

Detailed description of these outcrop intervals included macroscopic sedimentary structures, grain size, color, and bounding surfaces. Petrographic examination of 36 thin sections was completed in order to identify the microsedimentary structures in the black mudstone. Each section was examined with a stereomicroscope (Nikon AZ100M) in the Key Laboratory of Tectonic Controlled Mineralization and Oil Reservoir, Ministry of Land and Resources, Chengdu University of Technology (CDUT).

Forty-eight geochemical samples from the Wufeng and Longmaxi Formations at the Guanyinqiao section of Qijiang Country, Daijiagou section of Tongzi Country, and Rongxi section of Xiushan Country were analyzed. Prior to geochemical analysis, all fresh samples were crushed in a steel vessel and further ground to powder in an agate mill (200 mesh). The sample splits $(100 \mathrm{mg}$ ) for element analysis were heated in an oven at $105^{\circ}$ for $1-2 \mathrm{~h}$ and cooled to room temperature, then digested in a tightly sealed Teflon screw-cap vessel with $0.5 \mathrm{~mL}$ ultra-pure $\mathrm{HNO}_{3}+2.5 \mathrm{~mL} \mathrm{HF}+0.5 \mathrm{~mL} \mathrm{HClO}_{4}$, then dried. The dried sample was digested again with $1 \mathrm{~mL} \mathrm{HNO}_{3}+3 \mathrm{~mL}$ $\mathrm{H}_{2} \mathrm{O}$ until a clear solution was obtained. The solution was diluted to $1: 1000$ by mass and analyzed on a VG PQ2 Turbo inductively coupled plasma source mass spectrometer (ICP-MS) at the Institute of Tibetan Plateau Research, Chinese Academy of Sciences (CAS). Analytical precision for elemental analysis is generally greater than $4 \%$ of absolute concentrations.

\section{Results}

\subsection{Regional sedimentary characteristics}

Because of the paleoclimatic and paleoceanic importance of the Ordovician-Silurian transition, most sections near
Fig. 3 Lithologic compilation of the Wufeng-Guanyinqiao-Longmaxi Formation exposed at twelve sections located in the southeastern margin of the Sichuan Basin (for detailed locations see Fig. 1). The top figure represents a West to East directional cross-section and the bottom figure represents a South to North directional cross-section

the Qianzhong uplift have been studied in terms of biostratigraphy (e.g., Rong et al. 2011). In this study, the Guanyinqiao Formation at every section was used to accurately distinguish between the two series of black mudstone due to the similarity between the Wufeng and Longmaxi Formations.

In this study, two contrasting cross-sections ( $\mathrm{S}-\mathrm{N}$ and E-W) were constructed. First, the regional sediment thickness distribution of the E-W cross-section demonstrates that the thickest positions are located at the Linkou, Nanbazi, and Rongxi sections in the Wufeng Formation, and in the Guanyinqiao Formation. Depositional centers are located in the Linkou and Nanbazi sections. The regional sediment thickness distribution of the S-N crosssection shows that the thickest positions in the Wufeng Formation are located in the Nanbazi and Pingsheng sections and there is a hiatus in the Xiangshuyuan section in the Wufeng Formation. In the Guanyinqiao Formation, the depositional center is located in the Nanbazi section, and the thickness is only up to $0.5 \mathrm{~m}$ in the Xiangshuyuan section ( $\mathrm{Li}$ et al. 2005) in the south, and $0.28 \mathrm{~m}$ in the Guanyinqiao section (Fig. 3) in the north.

The whole depositional history can be divided into two stages. The first stage includes the deposition of the Wufeng and Guanyinqiao Formations. This set of mudstones and limestones was deposited in a series of depressions orientated in a west-east direction, parallel to the spreading direction of the Qianzhong uplift. The two thickest depocenters are located at the Weixin $(>20 \mathrm{~m})$ and Tongzi locations ( $>14 \mathrm{~m}$ ) (Fig. 4a). The second stage involves the deposition of the Longmaxi Formation. This set of mudstones and silty mudstones was deposited in a series of depressions orientated in a west-east direction, and still parallel to the spreading direction of the Qianzhong uplift. The two thickest depocenters are located at Xingwen $(>350 \mathrm{~m})$ and Guanyinqiao $(>300 \mathrm{~m})$. The depocenter has migrated to the north after the first stage (Fig. 4b).

\subsection{Paleobiology characteristics}

The black mudstone of the Wufeng Formation is rich in graptolites and radiolaria (Fig. 5a-d; Guo et al. 2011; Liu et al. 2013). However, there are no radiolaria in the black mudstone of the Longmaxi Formation, which only contains graptolites (Chen et al. 2000, 2005). The Guanyinqiao 

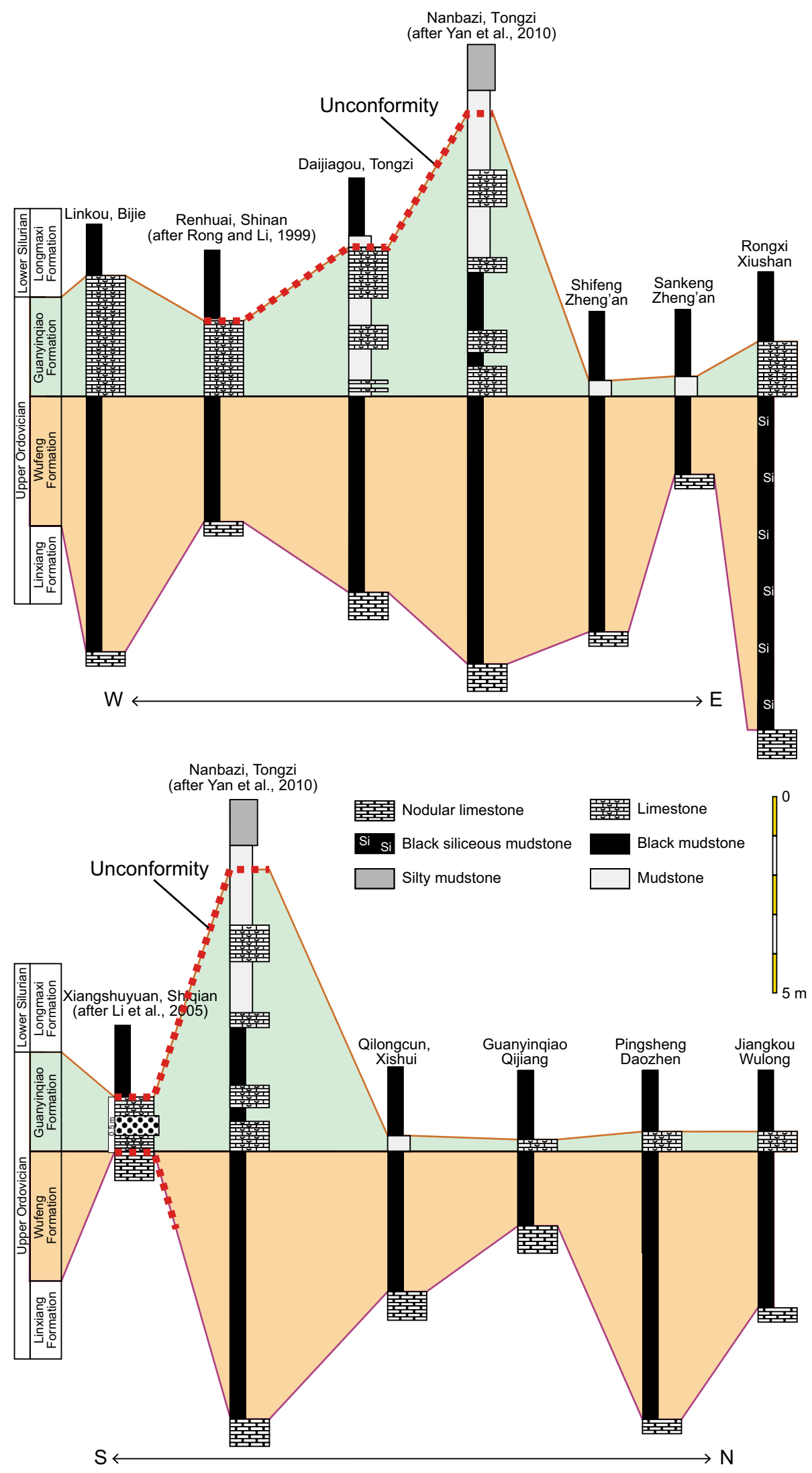


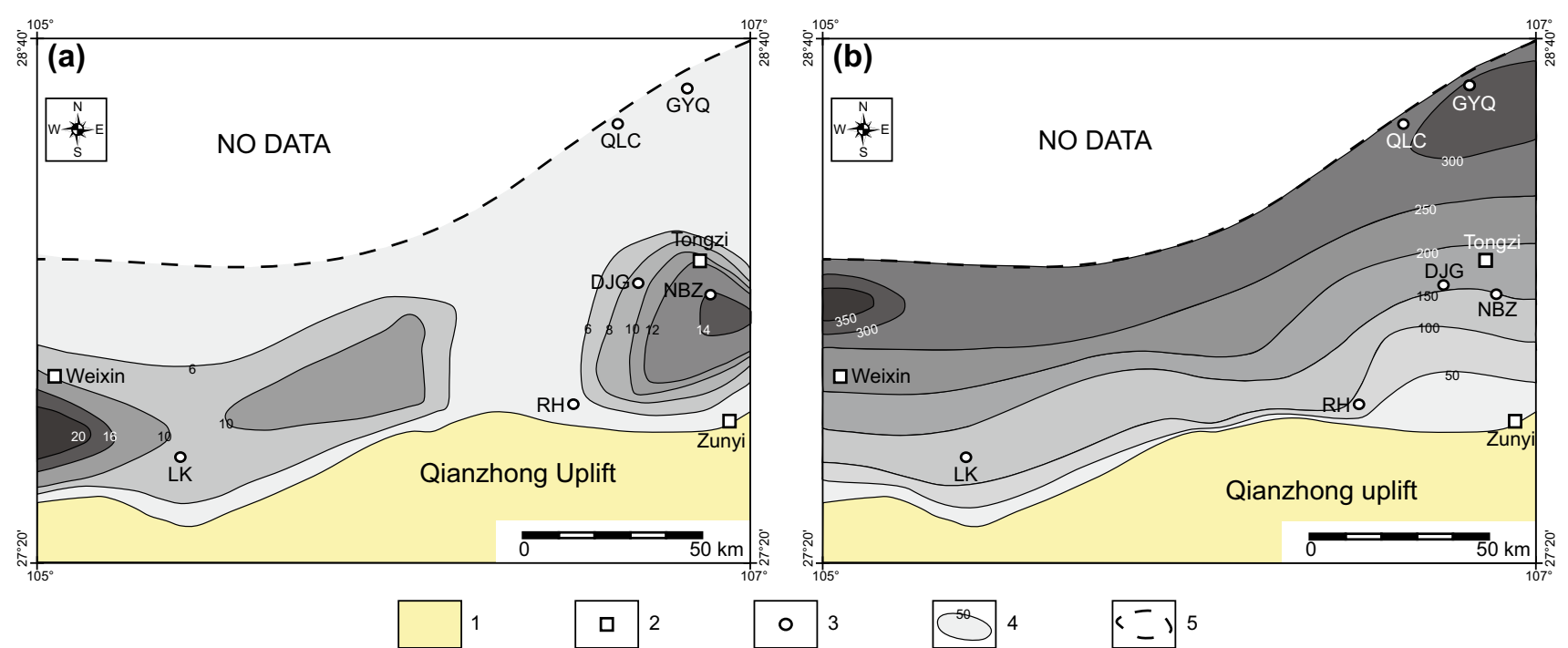

Fig. 4 Composite stratigraphic isopach map of a the WufengGuanyinqiao Formation and $\mathbf{b}$ the Longmaxi Formation in the 4: stratigraphic isopach line, 5: No data area. These regional data are northern margin of the Qianzhong uplift. 1: uplift, 2: city, 3: section, modified from BGMRGP (1987) and BGMRSP (1991)
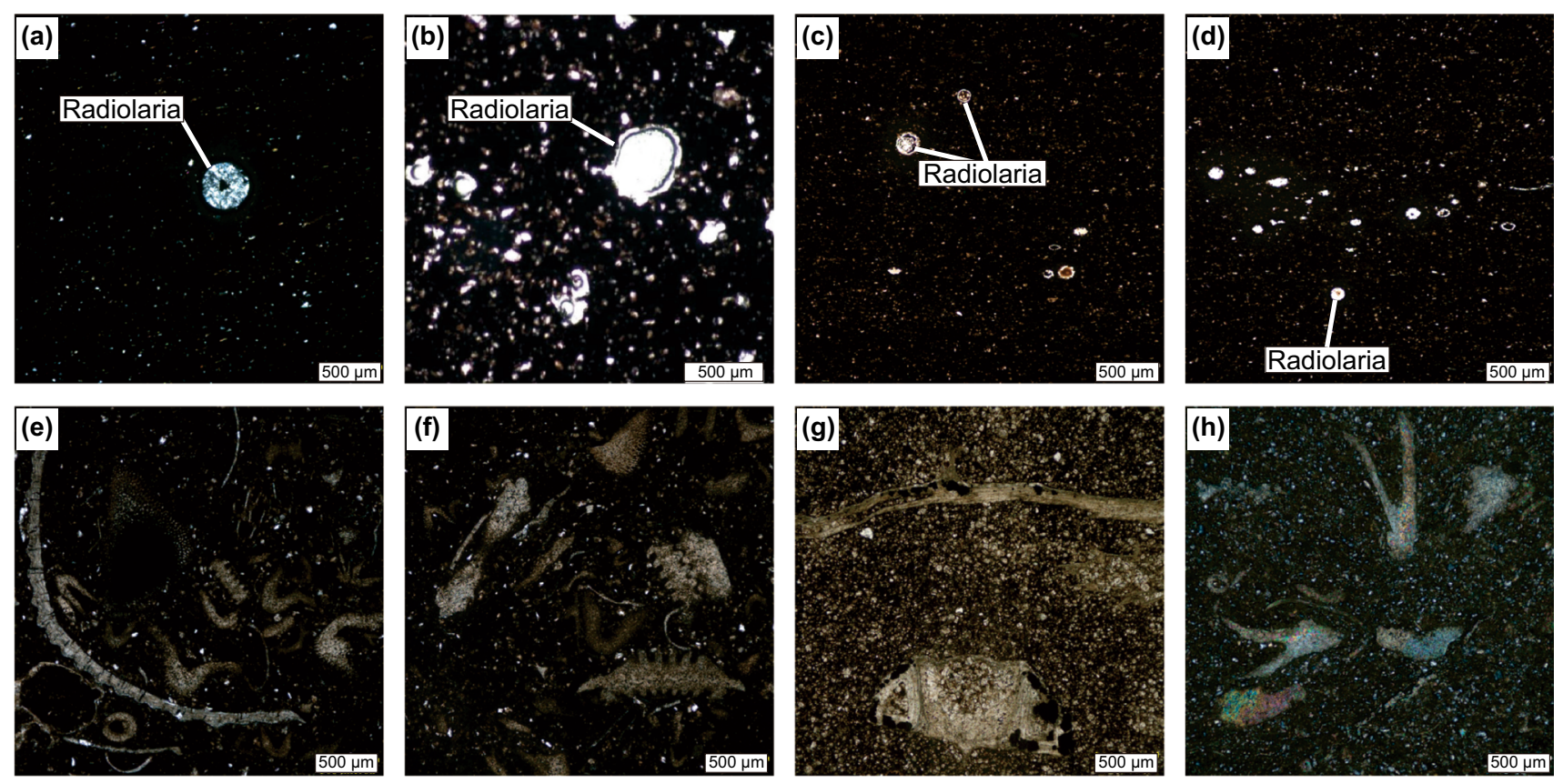

Fig. 5 Paleobiological and mineral characteristics of the Wufeng Formation (Top) and Guanyinqiao Formation (Bottom) in thin section. a sample TZ-3B; b sample TZ-5B; $\mathbf{c}, \mathbf{d}$ sample CXS1-7B; e, f sample TZ-3H; g, h sample CSX1-11B

Formation, containing gray, micritic limestone/mudstone with a relatively low abundance of shelly debris and bioclasts, is rich in crinoids and brachiopods, together with larger fragments of scattered rugose corals, gastropods, bryozoan, bivalves, and rare trilobites without an obvious arrangement (Fig. 5e-h).

\subsection{Microsedimentary features}

Lamination in mudstones is an important feature useful in providing clues to ancient sedimentary environments and processes. Various unique macro- and microfabrics associated with lamination type offer a useful frame of reference for interpretation of conditions of mudstone formation (O’Brien 1990). The Wufeng and Longmaxi Formations 
contain a variety of intergradational lithofacies dominated by fine-grained (clay- to silt-size) sediment. Based on vertical facies transitions, bed types, and sedimentary textures and structures, four main general lithofacies were identified: (1) indistinctly laminated mudstone; (2) parallellaminated mudstone; (3) nonparallel-laminated mudstone; (4) lenticular mudstone.

In this study, indistinctly laminated mudstone lithofacies are only concentrated in the Wufeng Formation and the basal part of the Longmaxi Formation based on the examination of thin sections. There is an abundance of moderately to well sorted, fine to very fine silt-sized sediment. Radiolaria and graptolites are evenly dispersed within a silt groundmass in the lithofacies, and there is a lack of internal structures or erosional contacts (Fig. 6). These lithofacies are interpreted to have been deposited from suspension fallout after transport into the deep water basin from hypopycnal flows (Abouelresh and Slatt 2011).

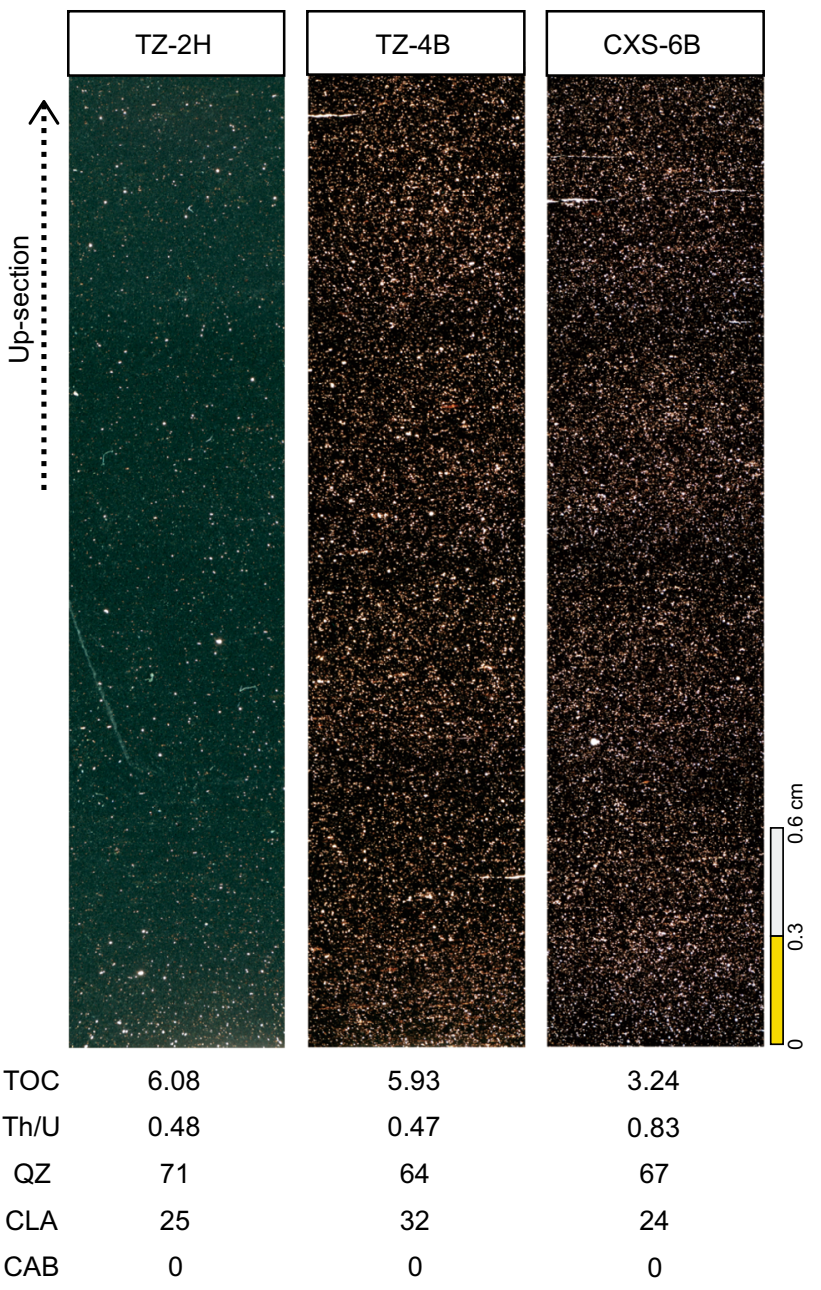

Fig. 6 Photomicrographs of a representative indistinctly laminated mudstone in the Wufeng Formation with the TOC content (\%), Th/U ratio, quartz content (\%, QZ), clay content (\%, CLA), and carbonate content $(\%, \mathrm{CAB})$
In parallel-laminated mudstone lithofacies only present in the Longmaxi Formation, laminae are horizontally bedded, and the lighter laminae/beds are composed of siltstone, limestone or dolomite (Figs. 7, 8), while the darker beds contain mudstone rich in clay which is interpreted to be associated with hypopycnal flows (Abouelresh and Slatt 2011). Sometimes, an erosive contact appears at the boundary between the silt-rich and clay-rich parts (Fig. 9).

Lenticular layers are lenses of granule-sized particles of quartz, feldspar, and rock fragments in fine- to very fine silt-sized sandstone. The long axes of lenticular layers are aligned parallel to the bedding plane (Figs. 7, 8, samples TZ-22B and TZ-18B-4). These lithofacies were deposited by multiple episodes of plastic flows and bottom currents in a shallow marine environment (e.g., Shanmugam 2002).

Low-angled laminae appear in the Longmaxi Formation (Figs. 7, 8, samples TZ-22B and TZ-13B-3). Laminae are composed of very-fine siltstone to claystone. Low-angle and micro-cross-stratification are the diagnostic characteristics with sharp-based laminae. This lithofacies is interpreted to have formed in a shallow marine environment associated with storms or bottom currents (Abouelresh and Slatt 2011).

\subsection{Total organic carbon content in the region}

TOC contents for the samples from five sections (the Rongxi, Nanbazi, Daijiagou, Qilongcun, and Guanyinqiao sections) range from $0.28 \%$ to $6.23 \%$ for the Wufeng, Guanyinqiao and Longmaxi Formations with a mean value of $2.25 \%$. The TOC value of the Wufeng Formation is relatively high $(2.17 \%-5.93 \%$, average $3.76 \%)$, and the TOC values of the Guanyinqiao and Longmaxi Formations are relatively poor $(1.37 \%-2.22 \%$, average $1.67 \%$; and $0.28 \%-6.23 \%$, average $1.86 \%$ ). Results of this study are in general agreement with earlier studies of the Nanbazi section indicating poorer TOC content in the Guanyinqiao and Longmaxi Formations (Yan et al. 2008). In terms of regional distribution, the TOC contents in the Rongxi, Nanbazi, and Daijiagou sections are higher and intervals of the organic-rich mudstones are thicker than those of the Guanyinqiao and Qilongcun sections, but the trend in Longmaxi Formation is just opposite (Fig. 10).

\subsection{Trace element geochemistry}

Previous studies have indicated that thorium is unaffected by redox conditions and remains insoluble as $\mathrm{Th}^{4+}$, but uranium exists as insoluble $\mathrm{U}^{4+}$ under highly reducing conditions, which leads to $\mathrm{U}$ enrichment in sediments, whereas it exists as soluble $\mathrm{U}^{6+}$ under oxidizing conditions, leading to $\mathrm{U}$ loss from sediments (Kimura and 


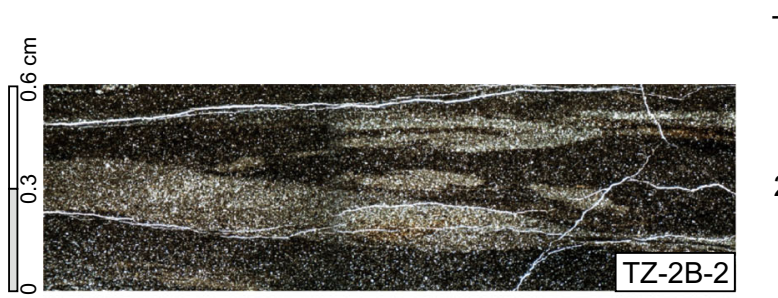

TOC Th/U QZ $\quad$ CLA $\quad$ CAB
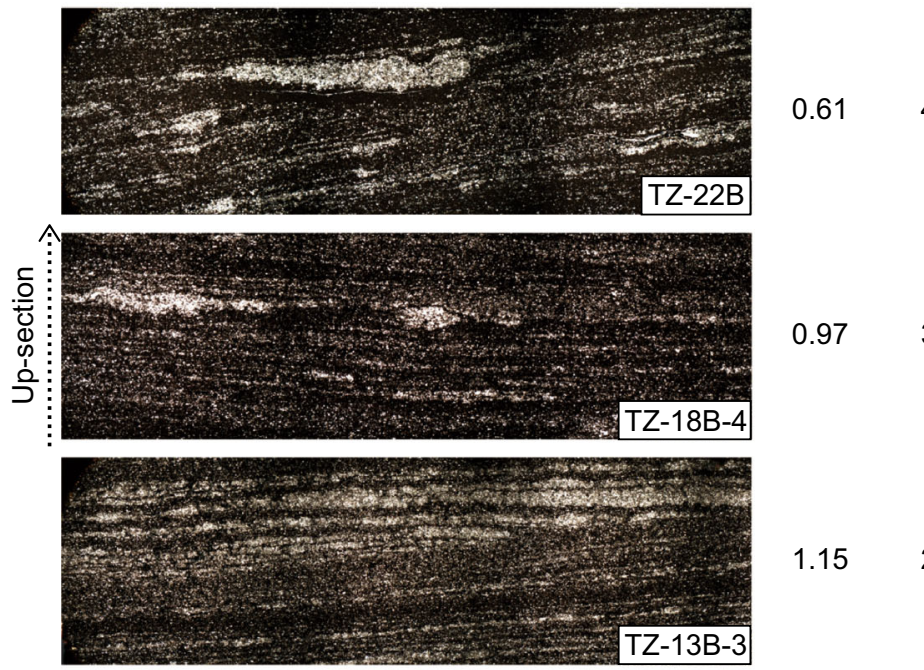

$\begin{array}{lllll}0.61 & 4.30 & 23 & 57 & 15\end{array}$

|l

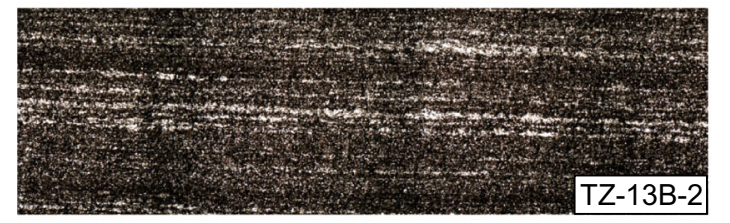

Fig. 7 Photomicrographs of representative parallel-laminated, nonparallel-laminated and lenticular mudstones in the Longmaxi Formation with TOC content $(\%)$, Th/U ratio, quartz content $(\%, \mathrm{QZ})$, clay content $(\%, \mathrm{CLA})$, and carbonate content $(\%, \mathrm{CAB})$

Watanabe 2001). As such, the $\mathrm{Th} / \mathrm{U}$ ratio has been used as a proxy for the redox conditions of depositional environments (Wignall 1994; Schulte et al. 2011). Wignall and Twitchett (1996) suggested that environments characterized by anoxic conditions yielded $\mathrm{Th} / \mathrm{U}$ ratios of $0-2$. This ratio has been widely accepted in subsequent black mudstone studies (Kimura and Watanabe 2001; Guo et al. 2007; Yan et al. 2009). Samples from four sections, including this study and some former sections, exhibit a wide range of $\mathrm{Th} / \mathrm{U}$ ratios, ranging from 0.466 to 5.707 (Fig. 11), which suggests frequent fluctuations in the environments from anoxic to oxic conditions over time.

In the Wufeng Formation, $\mathrm{Th} / \mathrm{U}$ ratios of these samples with higher TOC values (average $>2.0 \%$ ) are mostly lower than 2.0. The opposite phenomenon occurs in Guanyinqiao samples showing higher $\mathrm{Th} / \mathrm{U}$ ratios (average $>2.0$ ) and lower TOC values (average $<2.0 \%$ ). However, in the Longmaxi Formation, there is a complex change from lower $\mathrm{Th} / \mathrm{U}$ ratios (average $<2.0$ ) and higher TOC values (average $>2.0 \%$ ) in the lower part of the Longmaxi Formation to higher $\mathrm{Th} / \mathrm{U}$ ratios (average $>2.0$ ) and lower TOC values (average $<2.0 \%$ ) in the upper part of the Longmaxi Formation (Fig. 11).

Although the formation of organic matter is controlled by many factors, there is good agreement between $\mathrm{Th} / \mathrm{U}$ and TOC indicating anoxic conditions being the primary factor based on lower $\mathrm{Th} / \mathrm{U}$ ratios $(<2.0)$ pointing to anoxic conditions (Kimura and Watanabe 2001; Guo et al. 2007; Yan et al. 2009). 


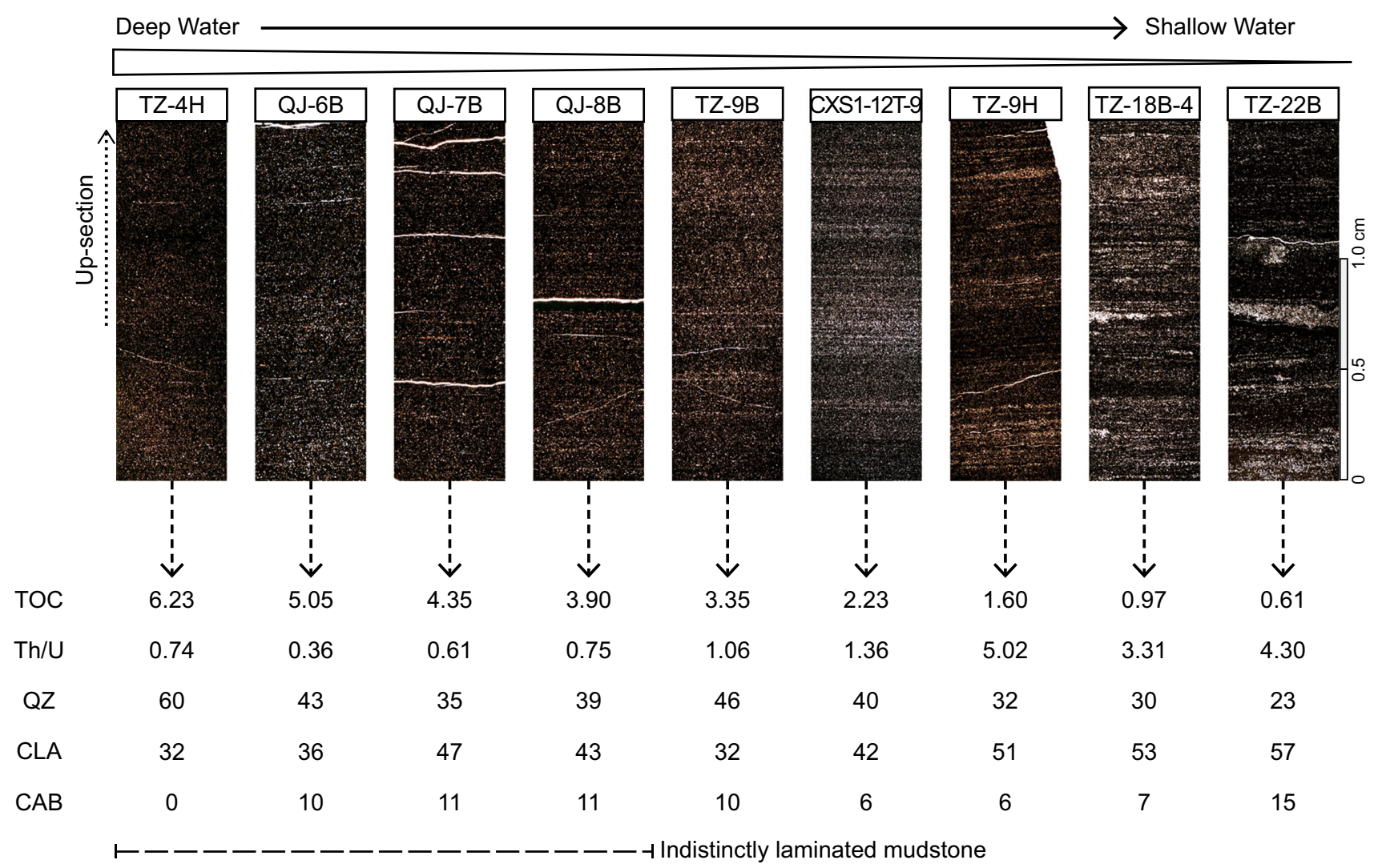

Parallel laminated mudstone $-\div-------1$

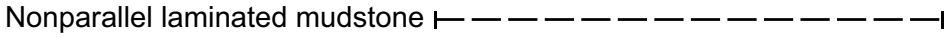

Fig. 8 Photomicrographs of indistinctly laminated, parallel-laminated and nonparallel-laminated mudstones in the Longmaxi Formation with TOC content $(\%), \mathrm{Th} / \mathrm{U}$ ratio, quartz content $(\%, \mathrm{QZ})$, clay content (\%, CLA), and carbonate content (\%, CAB)

\subsection{Mineral content}

The mineralogical analyses were performed on the same samples utilized for TOC determination. X-ray diffraction was employed to characterize the Wufeng-Longmaxi samples both qualitatively and quantitatively. There is a wide range of quartz contents varying from $17 \%$ to $76 \%$. The average content of quartz is $63 \%$ in the black mudstone of the Wufeng Formation, higher than that of Longmaxi Formation. Then, for the correlation between quartz and TOC contents, there is agreement in Longmaxi black mudstone samples indicating a moderate positive correlation (linear relationship, $R^{2}=0.6036$ ) but a poor negative correlation $\left(R^{2}=0.1349\right)$ is observed in Wufeng black mudstone samples (Fig. 12).

\section{Discussion}

Detailed petrographic studies show traces of bioturbation by micro-organisms in fauna and event beds with sharpbased, graded beds and organo-minerallic aggregates.
These are common in many organic-rich sediments at a micron to submillimeter scale (e.g., Macquaker and Gawthorpe 1993; Schieber 1999; Macquaker et al. 2007; Ghadeer and Macquaker 2012). This does not support the idea that long-term bottom water stagnation and anoxia is a prerequisite for the formation of organic carbon-rich sediments (e.g. Arthur and Sageman 1994; Sageman et al. 2003; Yan et al. 2009). Study of thin sections from the organic carbon-rich part (TOC $>2.0 \%$ ) of the Wufeng and Longmaxi Formations during our work not only revealed evidence for bioturbation, plankton, graptolites and deep water radiolaria, but also indicated indistinctly laminated mudstone was the main lithofacies (Figs. 7, 8). In addition, the relationship between the $\mathrm{Th} / \mathrm{U}$ ratio and TOC shows good correlation that most $\mathrm{Th} / \mathrm{U}$ ratios of organic carbonrich parts (TOC $>2.0 \%$ ) were lower than 2.0 (Fig. 11). All this data provides evidence that the organic-rich black mudstone of the Wufeng and Longmaxi Formations has been deposited into stagnant and anoxic bottom waters and preserved.

However, there are clear differences in the depositional environments for the Wufeng and Longmaxi Formations. 


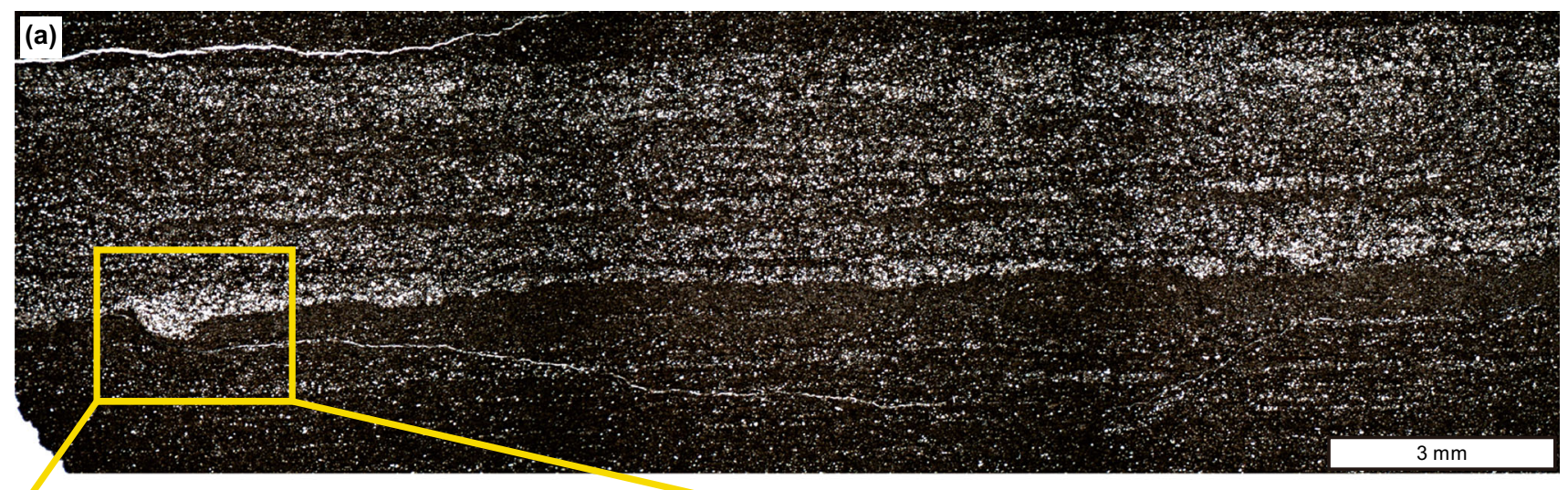

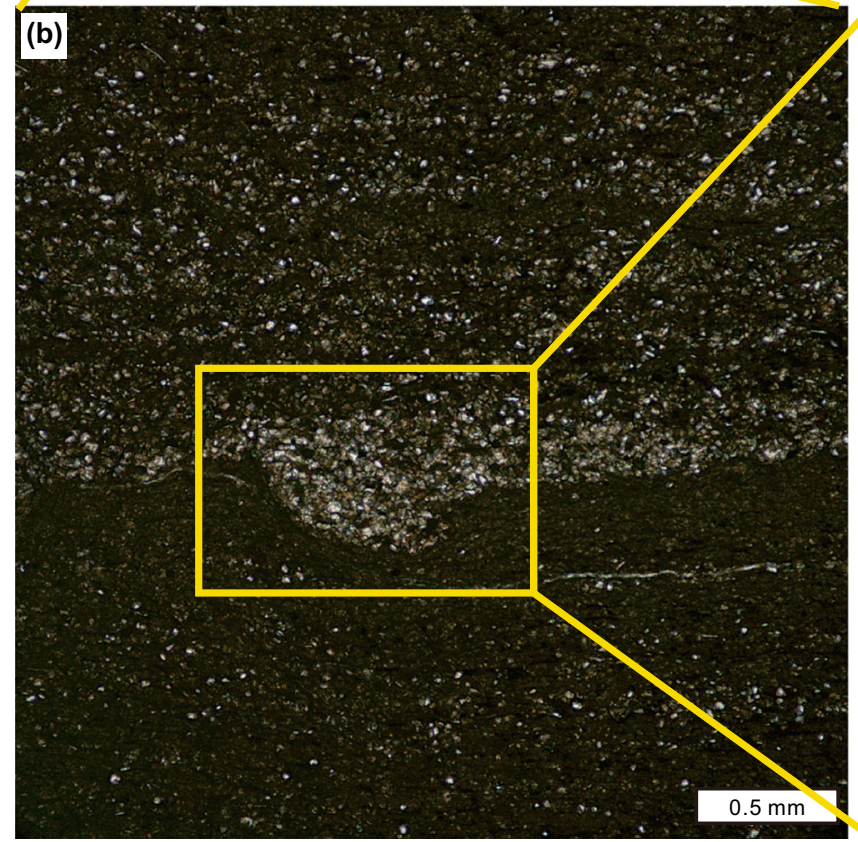

Fig. 9 a Photomicrographs of a representative erosive contact in the Longmaxi Formation (sample CXS1-19B). b Low-power optical microphotographs and c plane-polarized light photomicrographs

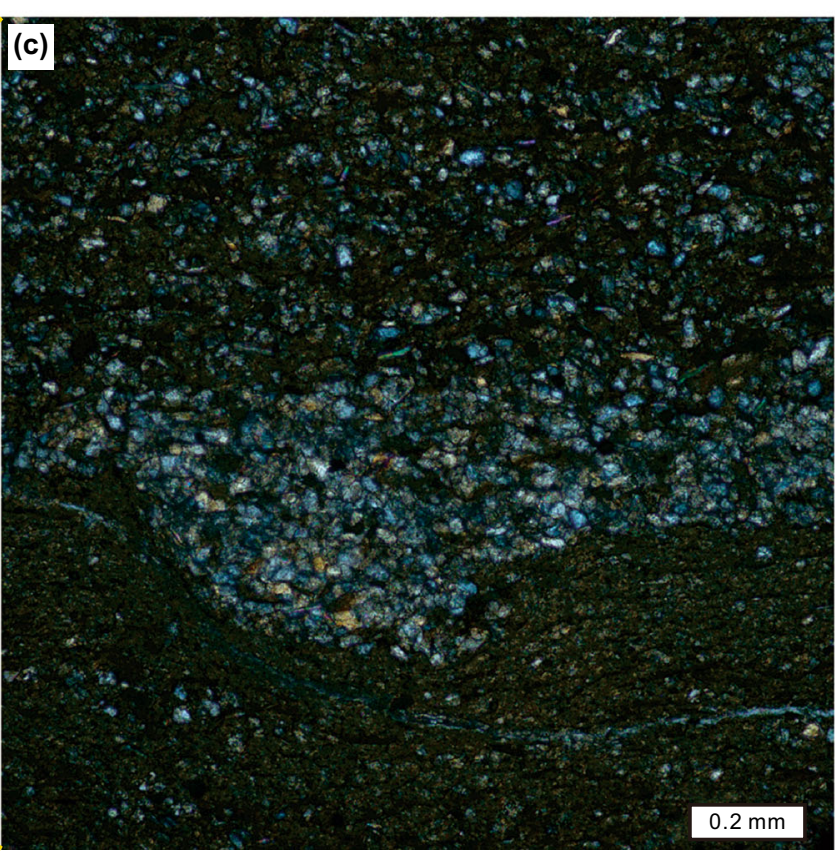

showing a classical erosive contact. Parameters of CXS1-19B include TOC $(0.49 \%), \mathrm{Th} / \mathrm{U}(4.77)$; quartz content $(36 \%)$, clay content $(45 \%)$, carbonate content $(4 \%)$

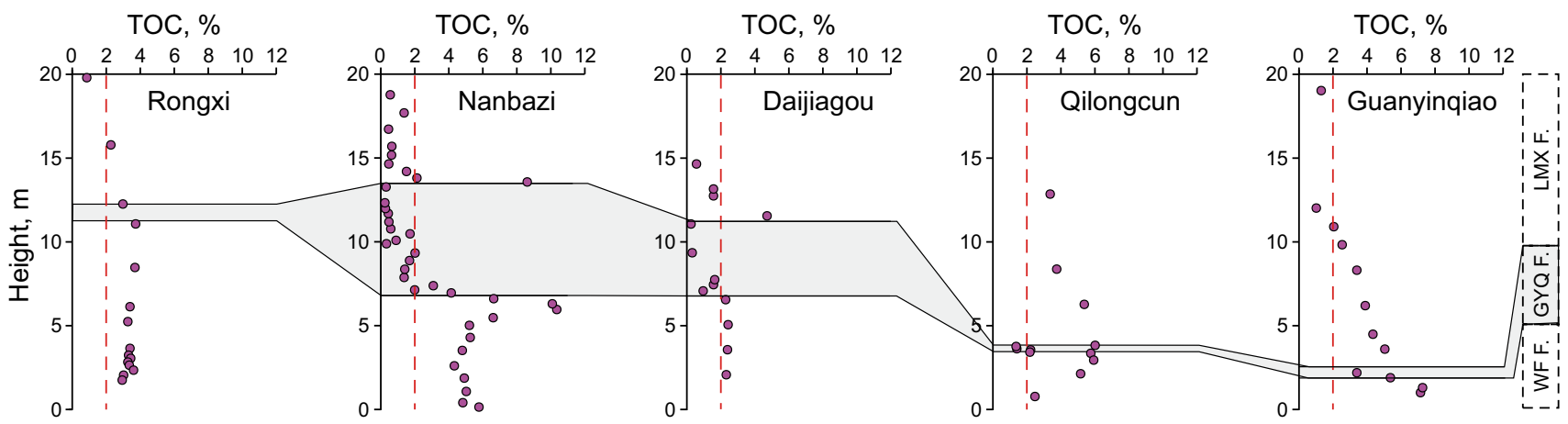

Fig. 10 Distribution tendency of TOC contents of the Wufeng-Guanyinqiao-Longmaxi Formation exposed in six sections located in the southern margin of the Sichuan Basin (for detailed locations see Fig. 1) 

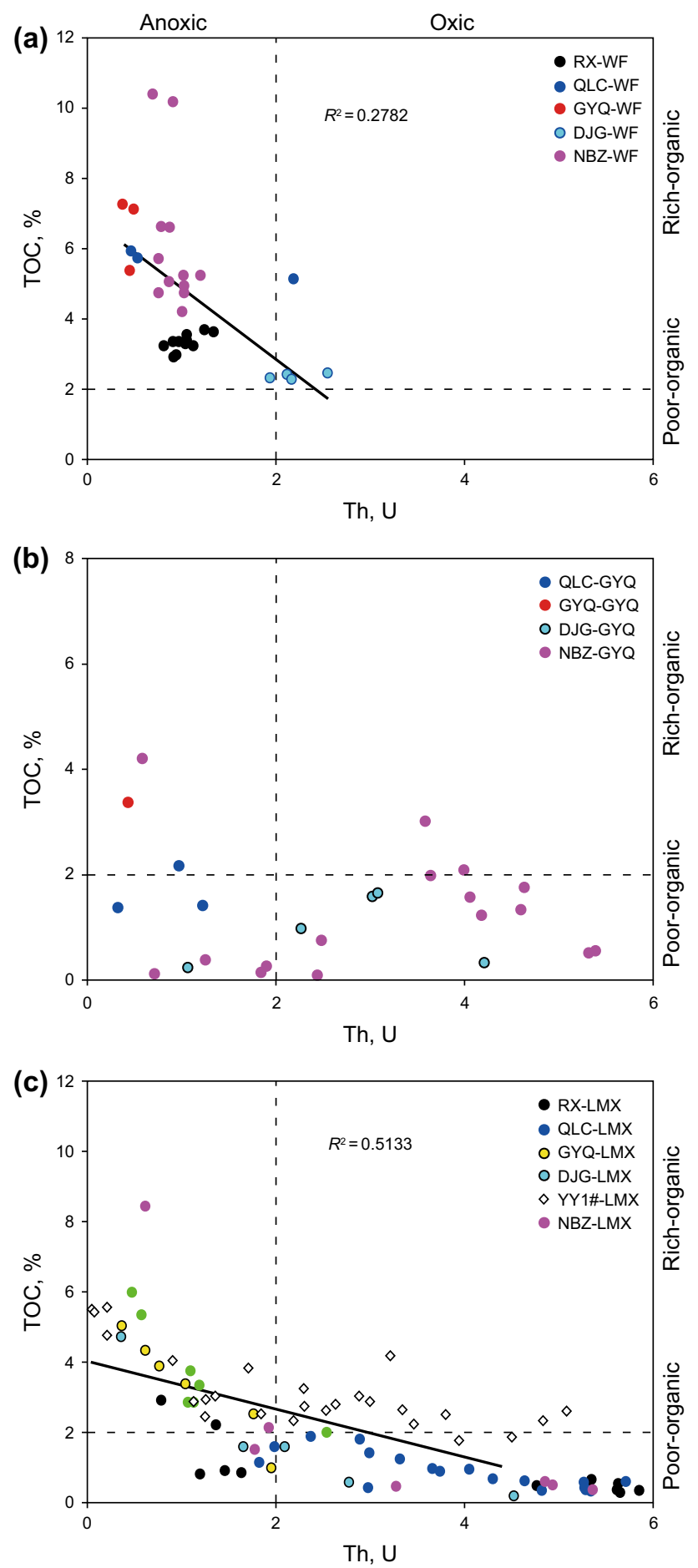

Fig. 11 Relationship between $\mathrm{Th} / \mathrm{U}$ ratios and TOC values in the Wufeng (a), Guanyinqiao (b) and Longmaxi (c) Formations. WF, Wufeng Formation; GYQ, Guanyinqiao Formation; LMX, Longmaxi Formation. XS, Rongxi section, Xiushan country; QJ, Guanyinqiao section, Qijiang country; DJG, Daijiagou section, Tongzi country; NBZ, Nanbazi section, Tongzi country (modified from Yan et al. 2008); TZ, Qilongcun section, Xishui country (modified from Ran et al. 2016); and YY1\#, Yuye 1 well, Pengshui country (modified from Guo et al. 2011)
First, radiolaria are limited to the Wufeng Formation in the Upper Yangtze (Huang et al. 1991; Liu et al. 2010; Ran et al. 2015), but graptolites are common in both the Wufeng and Longmaxi Formations (Su et al. 2002; Chen et al. 2004). Second, indistinctly laminated mudstones are the only lithofacies in the Wufeng Formation. On the other hand, in the Longmaxi Formation, the main lithofacies show a complicated mix from indistinctly laminated mudstone at the bottom to rhythmic mudstone in the middle to lenticular and nonparallel-laminated mudstone with erosive contacts (Figs. 7, 8, 9) at the top. Third, the relationship between $\mathrm{TOC}$ and $\mathrm{Th} / \mathrm{U}$ ratio shows a poor negative correlation (linear relationship, $R^{2}=0.2782$ ) in the Wufeng Formation, but a moderate positive correlation (linear relationship, $R^{2}=0.5133$ ) in the Longmaxi Formation (Fig. 11).

Above all, the evidence shows that the depositional environments for the Wufeng and Longmaxi Formations are not the same. In the Wufengian stage, the average $3.76 \% \mathrm{TOC}$, and the $\mathrm{Th} / \mathrm{U}$ ratios lower than 2.0 in most sections show that the organic-rich mudstones may have formed under mostly anoxic stagnant conditions with (Figs. 10, 11). Former studies have shown most anoxic intervals occur predominantly during sea-level high stands, because the water depth over a basin sill changes with sea level and can have profound effects on the nutrient regime of a basin (e.g., Werne et al. 2002; Arthur and Sageman 2005; Meyer and Kump 2008). Therefore, the fact that the sea level in the Katian stage was the highest in the Ordovician and Silurian in the region suggests favorable marine environments for organic enrichment (Chen et al. 2004; Haq and Schutter 2008). At the same time, the fact that siliceous radiolaria are limited in the Wufeng Formation provides evidence of a deep water origin (Fig. 5; Liu et al. 2010), and this is also supported by the increased content of quartz (Fig. 12). After the oxic and bioturbated Guanyinqiao Formation deposited in the Hirnantian low sea level stage (Fig. 5; Chen et al. 2004; Li et al. 2005; Yan et al. 2008; 2009), the depositional environment changed in the Longmaxi Formation. Following the sea level rising again (e.g., Haq and Schutter 2008), the lower part of the Longmaxi Formation deposited into mostly anoxic conditions forming the organic-rich mudstone. However, the organic-rich mudstone (TOC $>2.0 \%$ ) was limited to the Qijiang depocenter, including the Qilongcun and Guanyinqiao sections, but TOC of the black mudstone deposited into the Tongzi depocenter, including Nanbazi and Daijiagou sections, in the former stage was significantly lower than $2.0 \%$. This indicates the clear northward migration of the organic-rich mudstone deposited area and depocenter (Figs. 4, 10). Simultaneously, in the Longmaxi Formation, the lithofacies changed from bottom massive and rhythmic to top lenticular and nonparallel-laminated mudstones, 

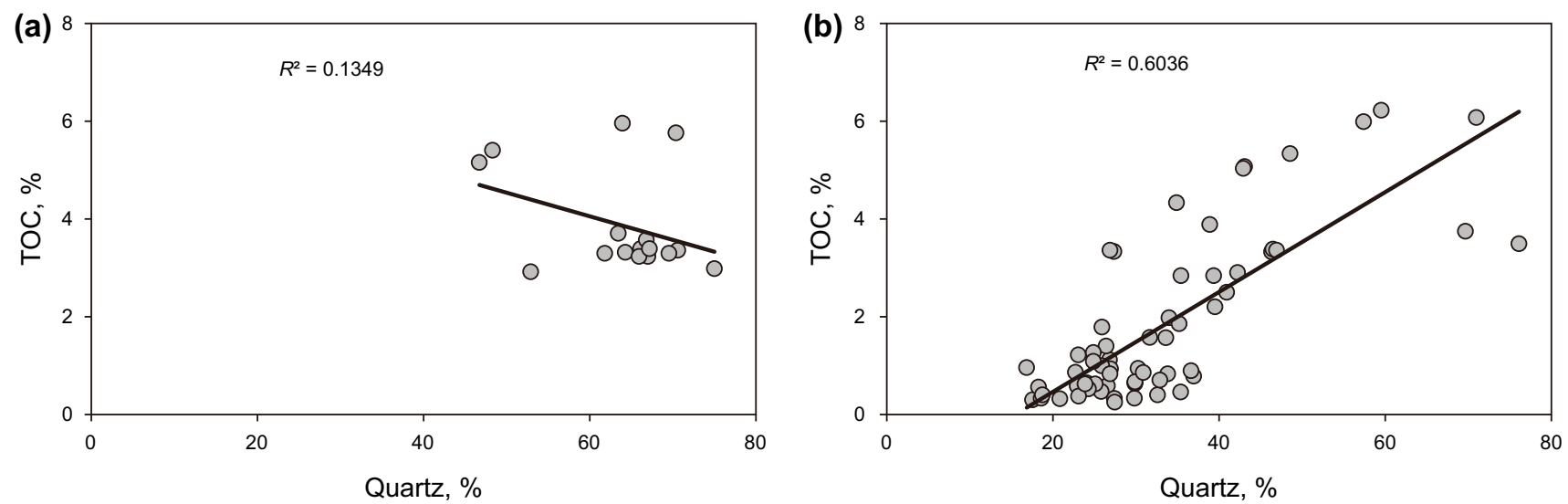

Fig. 12 Relationship between TOC and quartz contents in the Wufeng (a) and Longmaxi (b) Formations

indicating increased hydrodynamic conditions from a deep water environment to a shallow water setting (Figs. 7, 8), consistent with the fluctuation of the global sea level and the resulting sea level change in Yangtze block (Feng et al. 2000; Chen et al. 2004; Haq and Schutter 2008). The obvious change of the lithofacies shows the bottom anoxic conditions were disrupted by distal turbidites and dropping sea levels (Chen et al. 2004; Guo et al. 2011; Ran et al. 2016). As a result, the preferred condition for organic matter preservation had been destroyed, directly causing the decrease of TOC and quartz content and the increase of $\mathrm{Th} / \mathrm{U}$ ratio (Figs. 11, 12).

\section{Conclusions}

The main mechanisms responsible for sediment dispersal, delivery, and subsequent reworking that might influence organic carbon preservation in source rocks and gas mudstone were investigated in the Wufeng and Longmaxi Formations exposed in the Sichuan Basin. This succession is mainly dominated by four types of lithofacies: (a) indistinctly laminated mudstones (average 4.17, TOC, ranging from $2.14 \%$ to $10.24 \%$, with relatively high quartz content) which are the dominant facies in the Wufeng Formation and lower part of the Longmaxi Formation; (b) rhythmic mudstones (c) lenticular mudstones and (d) nonparallellaminated mudstones (average 1.15\% TOC, ranging from $0.20 \%$ to $8.45 \%$, with relatively low quartz content) which are the dominant facies in the upper part of the Longmaxi Formation. The data presented here suggest that organic matter preservation was controlled by low energy and anoxic conditions. Based on the obvious differences between the Wufeng and Longmaxi Formations, the two series of mudstones should be divided into independent stratigraphic units.
Acknowledgements This study was supported by the Science and Technology Support Program of Sichuan Province (No. 15ZC1390), National Natural Science Foundation of China (No. 41102064). The authors appreciate the reviewers' comments which improved the quality of the manuscript, and the welcome help of Zhifeng Zhang.

Open Access This article is distributed under the terms of the Creative Commons Attribution 4.0 International License (http://creative commons.org/licenses/by/4.0/), which permits unrestricted use, distribution, and reproduction in any medium, provided you give appropriate credit to the original author(s) and the source, provide a link to the Creative Commons license, and indicate if changes were made.

\section{References}

Abouelresh MO, Slatt RM. Shale depositional processes: example from the Paleozoic Barnett Shale, Fort Worth Basin, Texas, USA. Cent Eur J Geosci. 2011;3(4):398-409. https://doi.org/10. 2478/s13533-011-0037-z.

Aplin AC, Macquaker JHS. Mudstone diversity: Origin and implications for source, seal, and reservoir properties in petroleum systems. AAPG Bull. 2011;95(12):2031-59. https://doi.org/10. 1306/03281110162.

Arthur MA, Sageman BB. Marine black shales: depositional mechanisms and environments of ancient deposits. Annu Rev Earth Planet Sci. 1994;22(1):499-551. https://doi.org/10.1146/ annurev.ea.22.050194.002435.

Arthur MA, Sageman BB. Sea-level control on source-rock development: perspectives from the Holocene Black Sea, the midCretaceous Western Interior Basin, and the late Devonian Appalachian basin. Spec Publ. 2005;82:35-59. https://doi.org/ 10.2110/pec.05.82.0035.

Bureau of Geology and Mineral Resources of Guizhou Province (BGMRGP). Regional geology of Guizhou province. Beijing: Geological Publishing House; 1987 (in Chinese).

Bureau of Geology and Mineral Resources of Sichuan Province (BGMRSP). Regional geology of Sichuan province. Beijing: Geological Publishing House; 1991 (in Chinese).

Chen X, Rong JY, Fan J, et al. A global correlation of biozones across the Ordovician-Silurian boundary. Acta Palaeontogica Sin. 2000;39(1):100-14 (in Chinese).

Chen X, Rong JY, Li Y, et al. Facies patterns and geography of the Yangtze region, South China, through the Ordovician and 
Silurian transition. Palaeogeogr Palaeoclimatol Palaeoecol. 2004;204(2-4):353-72. https://doi.org/10.1016/S00310182(03)00736-3.

Chen X, Melchin MJ, Sheets HD. Patterns and processes of latest Ordovician graptolite extinction and recovery based on data from south China. J Paleontol. 2005;79(5):842-61. https://doi. org/10.1666/0022-3360(2005)079\%5b0842:PAPOLO\%5d2.0. $\mathrm{CO} ; 2$.

Chen SB, Zhu YM, Wang HY, et al. Shale gas reservoir characterisation: a typical case in the southern Sichuan Basin of China. Energy. 2011;36(11):6609-16. https://doi.org/10.1016/j.energy. 2011.09.001

Chen X, Fan JX, Chen Q, et al. Toward a stepwise Kwangsian orogeny. Sci China (Ser D) Earth Sci. 2014;57(3):379-87.

Feng HZ, Erdtmann BD, Early Wang HF. Paleozoic whole-rock Ce anomalies and secular eustatic changes in the Upper Yangtze region. Sci China (Ser D) Earth Sci. 2000;43(3):328-36. https:// doi.org/10.1007/BF02906829.

Ghadeer SG, Macquaker JHS. The role of event beds in the preservation of organic carbon in fine-grained sediments: analyses of the sedimentological processes operating during deposition of the Whitby Mudstone Formation (Toarcian, Lower Jurassic) preserved in northeast England. Mar Pet Geol. 2012;35(1):309-20. https://doi.org/10.1016/j.marpetgeo.2012. 01.001 .

Guo TL, Zhang HR. Formation and enrichment mode of Jiaoshiba shale gas field, Sichuan Basin. Pet Explor Dev. 2014;41(1):31-40. https://doi.org/10.1016/S18763804(14)60003-3.

Guo QJ, Shields GA, Liu CQ, et al. Trace element chemostratigraphy of two Ediacaran-Cambrian successions in South China: implications for organosedimentary metal enrichment and silicification in the early Cambrian. Palaeogeogr Palaeoclimatol Palaeoecol. 2007;254(1-2):194-216. https://doi.org/10.1016/j. palaeo.2007.03.016.

Guo L, Jiang ZX, Zhang JC, Li YX. Paleoenvironment of Lower Silurian black shale and its significance to the potential of shale gas, southeast of Chongqing, China. Energy Explor Exploit. 2011;29(5):597-616. https://doi.org/10.1260/0144-5987.29.5. 597.

Haq BU, Schutter SR. A chronology of Paleozoic sea-level changes. Science. 2008;322(5898):64-8. https://doi.org/10.1126/science. 1161648.

Huang ZC, Huang ZJ, Cheng ZN. Volcanic rock and radiolarian silicilith of Wufeng Formation in Lower Yangtze region. Acta Sedimentol Sin. 1991;9(2):1-14 (in Chinese).

Kimura H, Watanabe Y. Ocean anoxia at the Precambrian-Cambrian boundary. Geology. 2001;29(11):995-8. https://doi.org/10.1130/ 0091-7613(2001)029\%3c0995:OAATPC\%3e2.0.CO;2.

Li Y, Matsrumoto R, Kershaw S. Sedimentary and biotic evidence of a warm-water enclave in the cooler oceans of the latest Ordovician glacial phase, Yangtze Platform, South China block. Isl Arc. 2005;14(4):623-35. https://doi.org/10.1111/j.1440-1738. 2005.00472.x.

Li YF, Fan TL, Zhang JC, et al. Impact of paleoenvironment, organic paleoproductivity, and clastic dilution on the formation of organic-rich shales: a case study about the Ordovician-Silurian black shales, southeastern Chongqing, South China. Arab J Geosci. 2015;8(12):10225-39. https://doi.org/10.1007/s12517015-1944-y.

Liang DG, Guo TL, Chen JP, et al. Distribution of four suits of regional marine source rocks. Mar Origin Pet Geol. 2008;13(2):1-16 (in Chinese).

Liang C, Jiang ZX, Cao YC, et al. Deep-water depositional mechanisms and significance for unconventional hydrocarbon exploration: a case study from the lower Silurian Longmaxi shale in the southeastern Sichuan Basin. AAPG Bull. 2016;100(5):773-94. https://doi.org/10.1306/02031615002.

Liu W, Xu XS, Feng X, et al. Radiolarian siliceous rocks and palaeoenvironmental reconstruction for the Upper Ordovician Wufeng Formation in the middle-upper Yangtze area. Sediment Geol Tethyan Geol. 2010;30(3):65-70 (in Chinese).

Liu SG, Deng B, Li ZW, et al. Architecture of basin-mountain systems and their influences on gas distribution: a case study from the Sichuan basin, South China. J Asian Earth Sci. 2012;47(1):204-15. https://doi.org/10.1016/j.jseaes.2011.10. 012.

Liu SG, Ma WX, Jansa L, et al. Characteristics of the shale gas reservoir rocks in the Lower Silurian Longmaxi Formation, East Sichuan Basin, China. Energy Explor Exploit. 2013;31(2):187-219. https://doi.org/10.1260/0144-5987.31.2. 187.

Macquaker JHS, Bohacs KM. On the accumulation of mud. Science. 2007;318(5857):1734-5. https://doi.org/10.1126/science. 1151980 .

Macquaker JHS, Gawthorpe RL. Mudstone lithofacies in the Kimmeridge Clay Formation, Wessex basin: implications for the origin and controls on the distribution of mudstones. J Sediment Petrol. 1993;64A(4):927-32. https://doi.org/10.1306/D4267F282B26-11D7-8648000102C1865D.

Macquaker JHS, Taylor KG, Gawthorpe RL. High-resolution facies analyses of mudstones: implication for paleoenvironmental and sequence stratigraphic interpretations of offshore ancient muddominated successions. J Sediment Res. 2007;77(4):324-39. https://doi.org/10.2110/jsr.2007.029.

Meyer KM, Kump LR. Oceanic euxinia in earth history: causes and consequences. Annu Rev Earth Planet Sci. 2008;36(1):251-88. https://doi.org/10.1146/annurev.earth.36.031207.124256.

O'Brien NR. Significance of lamination in Toarcian (Lower Jurassic) shales from Yorkshire, Great Britain. Sediment Geol. 1990; 67(1-2):25-34. https://doi.org/10.1016/0037-0738(90)90025-O.

Potter PE, Maynard JB, Depetris PJ. Mud and mudstones: introduction and overview, vol. 65(24). Berlin: Springer; 2005. p. 8391-4.

Ran B, Liu SG, Jansa L, et al. Origin of the Upper Ordovician-lower Silurian cherts of the Yangtze block, South China, and their palaeogeographic significance. J Asian Earth Sci. 2015;108:1-17. https://doi.org/10.1016/j.jseaes.2015.04.007.

Ran B, Liu SG, Jansa L, et al. Reservoir characteristics and preservation conditions of Longmaxi shale in the Upper Yangtze block, South China. Acta Geologica Sin (Engl Ed). 2016;90(6):2182-205.

Rong JY, Chen X, Wang Y, et al. Northward expansion of Central Guizhou Oldland through the Ordovician and Silurian transition: evidence and implications. Sci China (Ser D) Earth Sci. 2011;41(10):1407-15.

Sageman BB, Murphy AE, Werne JP, et al. A tale of shales: the relative roles of production, decomposition, and dilution in the accumulation of organic-rich strata, Middle-Upper Devonian, Appalachian basin. Chem Geol. 2003;195(1):229-73. https://doi. org/10.1016/S0009-2541(02)00397-2.

Schieber J. Distribution and deposition of mudstone facies in the Upper Devonian Sonyea Group of New York. J Sediment Res. 1999;69(4):909-25. https://doi.org/10.1306/D4268AB8-2B2611D7-8648000102C1865D.

Schulte P, Scheibner C, Speijer RP. Fluvial discharge and sea-level changes controlling black shale deposition during the PaleoceneEocene Thermal Maximum in the Dababiya Quarry section, Egypt. Chem Geol. 2011;285(1-4):167-83. https://doi.org/10. 1016/j.chemgeo.2011.04.004. 
Shanmugam G. Ten turbidite myths. Earth Sci Rev. 2002;58(3):313-43. https://doi.org/10.1016/S00128252(02)00065-X.

$\mathrm{Su}$ WB, He LQ, Wang YB, et al. K-bentonite beds and highresolution integrated stratigraphy of the uppermost Ordovician Wufeng and the lowest Silurian Longmaxi Formations in South China. Sci China. 2002;32(3):207-19 (in Chinese).

Wang K, Chatterton BDE, Wang Y. An organic carbon isotope record of Late Ordovician to Early Silurian marine sedimentary rocks, Yangtze Sea, South China: implications for $\mathrm{CO}_{2}$ changes during the Hirnantian glaciation. Palaeogeogr Palaeoclimatol Palaeoecol. 1997;132(1-4):147-58. https://doi.org/10.1016/S00310182(97)00046-1.

Werne JP, Sageman BB, Lyons TW, et al. An integrated assessment of a "type euxinic" deposit: evidence for multiple controls on black shale deposition in the middle Devonian Oatka Creek Formation. Am J Sci. 2002;302(2):110-43. https://doi.org/10. 2475/ajs.302.2.110.

Wignall PB. Black shales. New York: Oxford University Press; 1994.

Wignall PB, Twitchett RJ. Oceanic anoxia and the end Permian mass extinction. Science. 1996;272(5265):1155-8. https://doi.org/10. 1126/science.272.5265.1155.
Yan DT, Chen DZ, Wang QC, et al. Environment redox changes of the Yangtze Sea during the Ordo-Silurian transition. Acta Geologica Sin (Engl Ed). 2008;82(3):679-89. https://doi.org/ 10.1111/j.1755-6724.2008.tb00619.x.

Yan DT, Chen DZ, Wang QC, et al. Geochemical changes across the Ordovician-Silurian transition on the Yangtze Platform, South China. Sci China Earth Sci. 2009;52(1):38-54. https://doi.org/10. 1007/s11430-008-0143-z.

Yang R, He S, Wang X, et al. Paleo-ocean redox environments of the Upper Ordovician Wufeng and the first member in lower Silurian Longmaxi Formations in the Jiaoshiba area, Sichuan Basin. Can J Earth Sci. 2016;53:426-40. https://doi.org/10.1139/cjes-20150210.

Zhai GM. Petroleum geology of China. Beijing: Petroleum Industry Press; 1989. p. 96-109 (in Chinese).

Zhao JH, Jin ZJ, Jin ZK, et al. Applying sedimentary geochemical proxies for paleoenvironment interpretation of organic-rich shale deposition in the Sichuan Basin, China. Int J Coal Geol. 2016;163:52-71. https://doi.org/10.1016/j.coal.2016.06.015. 